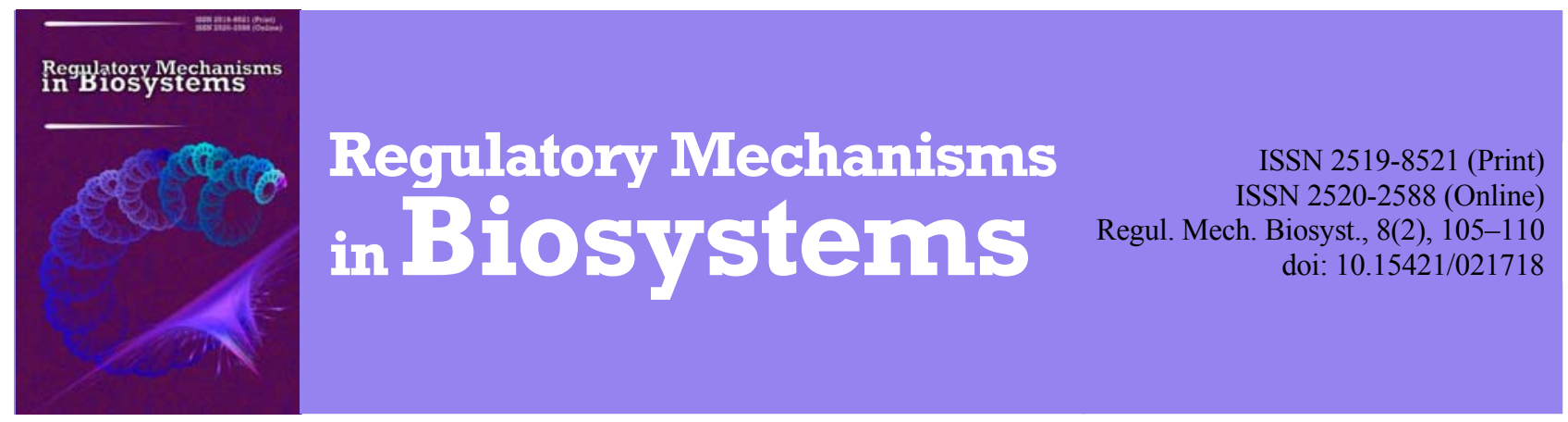

\title{
Levels of C-terminal propeptide of type I procollagen and oxyproline in patients with systemic lupus erythematosus: The relationship between the course of the disease and the structural and functional state of bone tissue
}

\author{
S. V. Shevchuk, L. P. Denyschych, L. I. Marynych \\ National Pirogov Memorial Medical University, Vinnytsya, Ukraine
}

Article info

Received 18.02.2017

Received in revised form 14.03.2017

Accepted 17.03.2017

National Pirogov

Memorial Medical University,

Khmelnytske Shosse, 104

Vinnytsya, 21100, Ukraine

Tel. +38-067-397-80-46

E-mail:shevssv2@mail.ru

\begin{abstract}
Shevchuk, S. V., Denyschych, L. P., \& Marynych, L. I. (2017). Levels of C-terminal propeptide of type I procollagen and oxyproline in patients with systemic lupus erythematosus: The relationship between the course of the disease and structural and the functional state of bone tissue. Regulatory Mechanisms in Biosystems, 8(2), 105-110. doi:10.15421/021718

The high prevalence of osteoporosis in patients with systemic lupus erythematosus (SLE) makes it necessary to study the abnormalities in bone metabolism, its relationship with reduced bone mineral density (BMD) and the impact of the disease on it. The aim of this study was to determine serum levels of C-terminal propeptide of type I procollagen (PICP) and oxyproline in patients with SLE, their comparison with the structural and functional state of the patients' bone tissue and the course of the disease. We examined 58 female SLE patients. The mean age of the patients was 45.1 years. The control group included 29 healthy individuals,corresponding in age and sex with the researched group. For every patient, data were recorded on age, body mass index (BMI), menstrual history, smoking, chronic SLE damage (SLICC/ACR DI) and disease activity score (SLEDAI), cumulative glucocorticoid dose, serum concentrations of interleukin-6 (IL-6) and C-reactive protein (CRP), bone formation marker (C-terminal propeptide of type I procollagen) and bone resorption marker (oxyproline). In all patients BMD was measured by DXA (Dual-energy X-ray absorptiometry) at two sites. To determine vertebral compression fractures, female SLE patients were examined with an $\mathrm{x}$-ray of the thoracic and lumbar spine. We established that bone turnover markers showed a significant difference between the SLE patients and the control group, with lower levels of PICP and higher levels of oxyproline in the SLE patients. Alterations of bone metabolism were associated with the severity of the disease, active inflammation (high levels of CRP and IL-6), the age of the patients, and the high cumulative glucocorticoid dose but no correlation was found with disease duration, BMI and smoking. Patients with osteopenia, osteoporosis and fractures were significantly more frequently found among patients with reduced bone formation and increased bone resorption rate. Thus, our findings showed that female SLE patients have alterations of bone metabolism in the form of increasing serum oxyproline and reducing serum C-terminal propeptide of type I procollagen, the correction of which would slow the progression of adverse structural and functional changes in the bone tissue.
\end{abstract}

Keywords: osteoporosis; bone turnover; bone mineral density

\section{Рівні С-кінцевого пропептиду проколагену I типу та оксипроліну у сироватці крові хворих на системний червоний вовчак: зв'язок із структурно-функціональним станом кісткової тканини та перебігом захворювання}

\author{
С. В. Шевчук, Л. П. Денищич, Л. І. Маринич
}

\section{Вінницький наџіональний медичний університет імені М. І. Пирогова, Вінниия, Україна}

Вивчено рівні С-кінцевого пропептиду проколагену I типу (РІСР) та оксипроліну у сироватці крові хворих на системний червоний вовчак (СЧВ), їх співставлення із структурно-функціональним станом кісткової тканини та перебігом захворювання. Обстежено 58 жінок, хворих на СЧВ, і 29 практично здорових осіб відповідного віку та статі. Враховано традиційні та СЧВ-зумовлені чинники ризику розвитку остеопорозу, визначено вміст інтерлейкіну-6 (ІЛ-6) та С-реактивного білка (СРБ), маркерів синтезу (С-кінцевого пропептиду проколагену I типу) та резорбції (оксипроліну) кісткової тканини, вивчено мінеральну щільність кісткової тканини (МЩКТ), враховано наявність переломів. У хворих на СЧВ має місце пригнічення біосинтетичних і посилення резорбтивних процесів кісткової тканини. Метаболічний дисбаланс асоціюється $з$ тяжкістю перебігу захворювання, активністю запального процесу, віком хворих та високою сумарною дозою глюкокортикоїдів (ГК) і суттєво не залежить від тривалості захворювання, індексу маси тіла (IMT) та паління. У групі хворих з ознаками 
пригнічення біосинтетичних і посиленням деструктивних процесів у кістковій тканині достовірно частіше зустрічались особи 3 остеопенією та остеопорозом, а також із переломами. У жінок із СЧВ відбувається формування несприятливого метаболічного патерну у вигляді зростання рівнів оксипроліну та зниження рівнів С-кінцевого пропептиду проколагену I типу, корекція якого дозволить уповільнити прогресування несприятливих структурно-функціональних змін кісткової тканини.

Ключові слова: остеопороз; метаболізм кісткової тканини; мінеральна щільність кісткової тканини

Вступ

Нині достеменно встановлено, що більшість хворих на СЧВ мають ознаки ураження кістково-м'язової системи, серед яких чинне місце займає остеопороз (Bultink \& Lams, 2016; Rees et al., 2016). Частота остеопорозу у хворих із СЧВ вища, порівняно $з$ популяційним рівнем (Ajeganova et al., 2015; Rees et al., 2016; Wang et al., 2016). Тяжкість остеопорозу у хворих на СЧВ асоціюється 3 цілою низкою факторів. До них належать жіноча стать, тривалість та активність захворювання, ступінь ушкодження органів, глюкокортикоїдна терапія тощо (Bultink, 2012; Carli et al., 2016; Cramarossa et al., 2016).

Появі денситометричних змін у скелеті передує порушення метаболічного стану кісткової тканини. Зокрема, у 29-35\% хворих на СЧВ із переломами хребців реєструється незмінена МЩКТ (Li et al., 2009; Mendoza-Pinto et al., 2009). Отож залишається відкритим питання: зниження міцності кісткової тканини у хворих на СЧВ - результат іiї зростаючої резорбції чи пригніченого формування або їх поєднання? Вважається, що зниження МЩКТ у хворих на СЧВ - наслідок прискореного остеокластогенезу, індукованого прозапальними цитокінами (ФНП-альфа, ІЛ-1, ІЛ-6 і ІЛ-17) (Korczowska et al., 2003; Amarasekara et al., 2015). За даними Redlich et al. (2000), у хворих на СЧВ переважає сповільнений біосинтез кісткової тканини. В інших (Becker et al., 2001; Sun et al., 2015) дослідженнях взагалі не знайдено взаємозв'язку між уже морфологічно зміненою кісткою та метаболічним станом кісткової тканини у хворих на СЧВ. Залишається також мало вивченим зв'язок перебігу захворювання у формуванні метаболічних порушень кісткової тканини у хворих на СЧВ. Мета дослідження - оцінити рівні С-кінцевого пропептиду проколагену I типу та оксипроліну у сироватці крові хворих на СЧВ та їх співставлення із структурно-функціональним станом кісткової тканини та перебігом захворювання.

\section{Матеріал і методи досліджень}

В основну групу включено 58 жінок, хворих на СЧВ. Середній вік хворих основної групи дорівнював 45,4 $\pm 1,0$ років. Контрольну групу склали 29 практично здорових осіб відповідного віку та статі. Діагноз СЧВ установлювали 3 урахуванням критеріїв ACR (Hochberg, 1997) та формулювали за рекомендаціями Асоціації ревматологів України (2002). Для оцінювання активності захворювання використовували шкалу SLEDAI (Bombardier et al., 1992). За шкалою SLICC/ACR DI визначали важкість ушкодження органів (Gladman et al., 1996). У всіх обстежених оцінено традиційні (вік, паління, період репродуктивного віку, індекс маси тіла) та СЧВ-зумовлені (тривалість захворювання, прийом глюкокортикоїдів, цитостатиків, гідроксихлорохіну) чинники ризику остеопорозу. Також враховано застосування препаратів кальцію та вітаміну D, антиостеопоротичної терапії. Для кожної хворої визначено сумарну дозу глюкокортикоїдів.

Під час лабораторного обстеження активність запального процесу визначено за швидкістю осідання еритроцитів (ШОЕ), СРБ та ІЛ-6. Вміст інтерлейкіну-6 (ІЛ-6) у плазмі крові визначали імуноферментним методом із використанням стандартного набоpy фірми Calbiotech (Німеччина). Визначення вмісту C-реактивного білка в сироватці крові проводили імуноферментним методом, використовуючи стандартний набір фірми Diagnostic Automation Inc. (США). Оцінювання маркерів формування кісткової тканини проводили за визначенням рівнів С-кінцевого пропептиду проколагену I типу імуноферментним методом із використанням комерційних наборів MicroVuetm CICP EIA Kit (Quidel, США). Рівень оксипроліну у сироватці крові визначали за допомогою фотоелектроколориметра.

Для виявлення низькоенергетичних переломів хребців застосовували рентгенографію грудного та поперекового відділів хребта в бічній проекціії.

МЩКТ на рівні $\mathrm{L}_{1}-\mathrm{L}_{4}$ поперекового відділу хребта та проксимального відділу стегна визначали за допомогою двоенергетичної рентгенівської абсорбціометрії на апараті Hologic Discovery Wi (S/N 87227). Остеопорозом вважали зниження МЩКТ за Т-критерієм -2,5 SD та нижче. Остеопенія відповідала t-критерію від -1 до -2,5 SD.

Визначено середню арифметичну (M), стандартну похибку середньої величини (SE), відносні величини (абс., \%), рівень статистичної значущості (Р). Критерій Стьюдента (t) застосовано для оцінювання достовірності відмінностей середніх величин, критерій $\chi^{2}$ Пірсона - для відносних величин. Із метою визначення взаємозв'язку між показниками використано коефіцієнти рангової кореляції Спірмена (r).

\section{Результати та їх обговорення}

Вміст С-кінцевого пропептиду проколагену I типу та оксипроліну в сироватці крові осіб контрольної та основної групи істотно відрізнялись. За результатами персентильного аналізу (табл. 1) встановлено, що у 95\% осіб контрольної групи рівень РІСР перебував у діапазоні 75,0-146,8 нг/мл $\left(\mathrm{P}_{5}\right.$ $\left.\mathrm{P}_{95}\right)$, коли у хворих на СЧВ 95\% СІ становив $48,0-157,0$ нг/мл. Рівень оксипроліну в основній групі складав 12,1-24,9 нг/мл, а в осіб контрольної групи - 11,4-16,8 нг/мл. Оскільки в літературі ми не знайшли критеріїв оцінювання сироваткових рівнів PICP та оксипроліну, для подальшого аналізу обрано показники, які наближаються до $\mathrm{P}_{75}$ та $\mathrm{P}_{95}$ групи контролю. Оптимальним вважали рівень РІСР, вищий 92,0 нг/мл $\left(>\mathrm{P}_{25}\right)$, гранично низьким - 75,0-92,0 нг/мл $\left(\mathrm{P}_{25}-\mathrm{P}_{5}\right)$, низьким - нижче 75,0 нг/мл $\left(<\mathrm{P}_{5}\right)$. Рівень оксипроліну в сироватці крові вважали оптимальним за показників нижче 16,2 нг/мл ( $\left.<\mathrm{P}_{75}\right)$, гранично високим $16,2-16,8$ нг/мл $\left(\mathrm{P}_{75}-\mathrm{P}_{95}\right)$, високим - вище 16,8 нг/мл $\left(>\mathrm{P}_{95}\right)$.

Середній вміст РІСР у сироватці крові хворих на СЧВ дорівнював 92,9 $\pm 5,0$ нг/мл, тоді як у практично здорових осіб $107,8 \pm 4,3$ нг/мл, і був вищим на $13,8 \%$ (табл. 2). Частка осіб із низьким рівнем РІСР становила 39,0\% проти 6,9\% групи контролю. Середній рівень оксипроліну в основній групі дорівнював 17,0 $\pm 0,6$ нг/мл, в контрольній $-14,8 \pm 0,3$ нг/мл, або був на $14,8 \%$ нижчим. Частка осіб із високим рівнем оксипроліну у групі хворих на СЧВ суттєво не відрізнялась від такої в контрольній групі. Порушення процесів ремоделювання кісткової тканини асоціювалось зі зниженням МЩКТ у хворих на СЧВ, накопиченням осіб з остеопенією та остеопорозом. Середній вміст РІСР у хворих з ознаками остеопорозу був на $43,7 \%$ нижчим, ніж за нормального стану кістки, та дорівнював 56,1 $\pm 2,5$ нг/мл проти 99,7 \pm 7,6 нг/мл. Подібні, проте обернені взаємозв'язки відмічено і за рівнем оксипроліну. У хворих на СЧВ із переломами в анамнезі метаболізм кісткової тканини змінювався у бік пригнічення біосинтетичних процесів. Вміст РІСР на $31,2 \%$ нижчий в осіб із переломами, ніж без них, відповідно зростає частка пацієнтів 3 низьким рівнем PICP.

Отримані дані свідчать, що показники метаболічного стану кістки у жінок із СЧВ виявляють певну залежність від традиційних факторів ризику (табл. 3). Зі збільшенням віку хворих виявлялась чітка тенденція до сповільнення процесів формування кісткової тканини. У хворих старшого віку вміст РІСР на 23,0\% нижчий, 
ніж у хворих найменшої вікової групи. Збільшення віку також асоційоване 3 посиленням деструктивних процесів кісткової тканини, про що свідчить вищий (на 18,9\%) вміст оксипроліну у сироватці крові у хворих (старше 55 років) порівняно $з$ пацієнтами до 35 років.

Не знайдено чіткого взаємозв'язку між метаболічними зрушеннями кісткової тканини у хворих на СЧВ із тривалістю захворювання, палінням, а також IMT. Результати (табл. 4) дозволяють стверджувати, що збільшення індексу ушкодження вну- трішніх органів та сумарного показника активності захворювання за SLEDAI негативно відображається на метаболічному стані кісткової тканини. Підвищення індексу ушкодження вище 3 балів викликало тенденцію до зниження вмісту РІCР і підвищення вмісту оксипроліну. Достовірні зміни метаболічного стану кістки виявлено за умов високої активності захворювання за SLEDAI. Рівні PICP у групі (SLEDAI понад 18 балів) були нижчими на $25 \%$, а оксипроліну - вищими на $12,6 \%$, ніж в осіб із SLEDAI менше 18 балів.

\section{Таблиця 1}

Персентильний аналіз вмісту С-кінцевого пропептиду проколагену I типу та оксипроліну в сироватці крові практично здорових осіб і хворих із СЧВ

\begin{tabular}{|c|c|c|c|c|c|c|c|}
\hline \multirow{2}{*}{ Група } & \multirow{2}{*}{ Медіана } & \multicolumn{6}{|c|}{ С-кінцевий пропептид проколагену I типу, нг/мл } \\
\hline & & $\mathrm{P}_{5}$ & $\mathrm{P}_{10}$ & $\mathrm{P}_{25}$ & $\mathrm{P}_{75}$ & $\mathrm{P}_{90}$ & $\mathrm{P}_{95}$ \\
\hline Контроль, $\mathrm{n}=29$ & 106 & 75 & 75 & 92 & 125 & 142,6 & 146,8 \\
\hline Хворі із СЧВ, $\mathrm{n}=58$ & 78 & 48 & 51 & 60 & 125 & 142,7 & 157,0 \\
\hline \multicolumn{8}{|c|}{ Оксипролін, нг/мл } \\
\hline Контроль, $\mathrm{n}=29$ & 15,2 & 11,4 & 12,4 & 14,3 & 16,2 & 16,7 & 16,8 \\
\hline Хворі із СЧВ, $\mathrm{n}=58$ & 15,4 & 12,1 & 12,7 & 13,7 & 21,8 & 23,5 & 24,9 \\
\hline
\end{tabular}

Таблиця 2

Вміст С-кінцевого пропептиду проколагену I типу та оксипроліну в сироватці крові та їх зв'язок зі станом кісткової тканини

\begin{tabular}{|c|c|c|c|c|c|}
\hline & \multirow{3}{*}{ Групи хворих } & \multicolumn{4}{|c|}{ Маркери метаболізму кісткової тканини } \\
\hline & & \multicolumn{2}{|c|}{ С-кінцевий пропептид проколагену I типу, нг/мл } & \multicolumn{2}{|c|}{ оксипролін, нг/мЛ } \\
\hline & & $\mathrm{M} \pm \mathrm{SE}$ & $\begin{array}{c}\text { частка осіб із низьким } \\
\text { вмістом (<60 нг/мл) }\end{array}$ & $\mathrm{M} \pm \mathrm{SE}$ & $\begin{array}{l}\text { частка осіб із високим } \\
\text { вмістом (>16,0 нг/мл) }\end{array}$ \\
\hline & Контроль, $\mathrm{n}=29$ & $107,8 \pm 4,28$ & $2(6,9 \%)$ & $14,8 \pm 0,31$ & $8(27,5 \%)$ \\
\hline & Хворі на СЧВ, $\mathrm{n}=58$ & $92,9 \pm 5,01 *$ & $16(39,0 \%)^{*}$ & $17,0 \pm 0,57^{*}$ & $24(41,4 \%)$ \\
\hline \multicolumn{6}{|c|}{ у тому числі залежно від мінеральної щільності кісткової тканини } \\
\hline & Хворі на СЧВ з нормальним станом кістки, $\mathrm{n}=32$ & $99,7 \pm 7,61$ & $6(18,7 \%)$ & $16,4 \pm 0,77$ & $9(28,1 \%)$ \\
\hline & Хворі на СЧВ з остеопенією, $\mathrm{n}=19$ & $92,4 \pm 7,75$ & $4(21,0 \%)$ & $16,6 \pm 0,93$ & $9(47,4 \%)$ \\
\hline 5 & Хворі на СЧВ з остеопорозом, $\mathrm{n}=7$ & $56,1 \pm 2,49^{\#}$ & $6(85,7 \%)$ & $21,0 \pm 1,16^{\#}$ & $6(85,7 \%)$ \\
\hline \multicolumn{6}{|c|}{ у тому числі залежно від наявності переломів } \\
\hline & Хворі на СЧВ без переломів, $\mathrm{n}=54$ & $95,0 \pm 5,21$ & $11(20,4 \%)$ & $16,8 \pm 0,58$ & $21(38,9 \%)$ \\
\hline & Хворі на СЧВ з переломами, $\mathrm{n}=4$ & $65,3 \pm 13,55^{\gamma}$ & $2(50,0 \%)$ & $20,0 \pm 2,41$ & $3(75,0 \%)$ \\
\hline
\end{tabular}

Примітки: * - вірогідні відмінності щодо осіб контрольної групи; \# - вірогідні відмінності щодо пацієнтів із нормальним станом кісткової тканини; $\gamma$-відмінності стосовно хворих без переломів.

\section{Таблиця 3}

Зв'язок рівнів C-кінцевого пропептиду проколагену I типу та оксипроліну в сироватці крові з віком, тривалістю захворювання, ІМТ і палінням

\begin{tabular}{|c|c|c|c|c|}
\hline \multirow{3}{*}{ Групи хворих } & \multicolumn{4}{|c|}{ Маркери метаболізму кісткової тканини } \\
\hline & \multicolumn{2}{|c|}{ С-кінцевий пропептид проколагену I типу, нг/мл } & \multicolumn{2}{|c|}{ оксипролін, нг/мЛ } \\
\hline & $\mathrm{M} \pm \mathrm{SE}$ & $\begin{array}{c}\text { частка осіб із низьким } \\
\text { вмістом }(<60 \text { нг/мл) }\end{array}$ & $\mathrm{M} \pm \mathrm{SE}$ & $\begin{array}{l}\text { частка осіб із високим } \\
\text { вмістом (>16,0 нг/мл) }\end{array}$ \\
\hline \multicolumn{5}{|c|}{ залежно від віку } \\
\hline 1 До 35 років, $n=9$ & $110,9 \pm 14,6$ & $1(11,1 \%)$ & $14,86 \pm 0,53$ & $1(11,1 \%)$ \\
\hline $236-55$ років, $n=40$ & $89,8 \pm 5,9$ & $13(7,5 \%)$ & $17,36 \pm 0,74 *$ & $18(45,0 \%)$ \\
\hline 3 Понад 55 років, $\mathrm{n}=9$ & $89,2 \pm 12,1$ & $2(22,2 \%)$ & $17,65 \pm 1,40$ & $5(55,5 \%)$ \\
\hline \multicolumn{5}{|c|}{ залежно від тривалості захворювання } \\
\hline 4 До 5 років, $n=17$ & $88,2 \pm 9,6$ & $7(41,1 \%)$ & $17,6 \pm 1,12$ & $9(52,9 \%)$ \\
\hline 5 5-10 років, $\mathrm{n}=8$ & $87,0 \pm 15,3$ & $2(25,0 \%)$ & $17,4 \pm 1,41$ & $4(50,0 \%)$ \\
\hline 6 Понад 10 років, $\mathrm{n}=33$ & $96,9 \pm 6,4$ & $7(21,2 \%)$ & $16,8 \pm 0,76$ & $11(33,3 \%)$ \\
\hline \multicolumn{5}{|c|}{ залежно від паління } \\
\hline 7 Не палять, $\mathrm{n}=54$ & $93,2 \pm 5,2$ & $14(25,9 \%)$ & $17,1 \pm 0,60$ & $22(40,7 \%)$ \\
\hline 8 Палять, $\mathrm{n}=4$ & $89,5 \pm 23,4$ & $2(50,0 \%)$ & $16,6 \pm 2,03$ & $2(50,0 \%)$ \\
\hline \multicolumn{5}{|c|}{ залежно від IMT } \\
\hline 9 IMT до 25 кг $/ \mathrm{M}^{2}, \mathrm{n}=50$ & $95,5 \pm 5,3$ & $12(24,0 \%)$ & $16,95 \pm 0,63$ & $19(38,0 \%)$ \\
\hline 10 IMT понад 25 кг $/ \mathrm{M}^{2}, \mathrm{n}=8$ & $77,5 \pm 14,2$ & $4(50,0 \%)$ & $17,59 \pm 1,37$ & $5(62,5 \%)$ \\
\hline
\end{tabular}

Примітка: * - вірогідні відмінності щодо пацієнтів найменшої вікової групи.

Підвищення вмісту медіаторів запалення у сироватці крові, зокрема, інтерлейкіну-6 та СРБ асоціювалось із посиленням ознак кісткової деструкції та зниженням біосинтетичних процесів (табл. 5). Слід зазначити, що зміни маркерів метаболізму кісткової тканини за помірного зростання у сироватці крові ІЛ-6 та СРБ були несуттєвими, у той час як за високих рівнів показників активності вони значно посилювались. У хворих із високим рівнем ІЛ-6 (вище 20,0 нг/л) вміст PICP був нижчим (на $38,1 \%$ та $39,6 \%$, відповідно), ніж у хворих із гранично високим (12,5-20,0 нг/л) та оптимальним ( $<12,5$ нг/л) рівнями ІЛ-6. Достовірно зросла частка осіб із низьким рівнем РІСР з 6,7\% у групі з оптимальним рівнем ІЛ-6 до 55,6\% у групі з високим рівнем ІЛ-6. Підвищення вмісту ІЛ6 також асоціювалось із посиленням деструктивних процесів у кістковій тканині, про що свідчить вищий (на 12-39\%) рівень оксипроліну в осіб із високими рівнями цитокіну. Подібні асоціації виявлені також за рівнем СРБ. Результатами кореляційного аналізу додатково підтверджено наявність тісного взає- 
мозв'язку між концентрацією ІЛ-6 ( $\mathrm{r}=-0,24,0,54)$ та СРБ $(\mathrm{r}=$ $-0,49,0,51)$, відповідно, з рівнем РІСР та оксипроліну. Збільшення ГК навантаження також негативно відображалось на біосинтетичних і резорбтивних процесах кістки (табл. 6). На це вказує той факт, що у хворих із низькою та помірною сумарною дозою ГК зміни РІСР та оксипроліну були менш суттєвими, ніж в осіб із високою сумарною дозою ГК (понад
70 г). Частка пацієнтів із низьким рівнем РІСР і високим оксипроліну серед хворих із високою сумарною дозою ГК дорівнювала $41,1 \%$ та $88,2 \%$, відповідно, і була практично удвічі вищою, ніж в осіб із помірною чи низькою сумарною дозою ГК. Кореляційний аналіз також підтвердив наявність тісних асоціативних взаємозв'язків між сумарною дозою глюкокортикоїдів, з одного боку, та рівнем РІСР та оксипроліну - з іншого.

\section{Таблиця 4}

Зв'язок рівнів C-кінцевого пропептиду проколагену I типу та оксипроліну в сироватці крові з індексом ушкодження та сумарним показником активності запального процесу SLEDAI

\begin{tabular}{|c|c|c|c|c|}
\hline \multirow{3}{*}{ Групи хворих } & \multicolumn{4}{|c|}{ Маркери метаболізму кісткової тканини } \\
\hline & \multicolumn{2}{|c|}{ С-кінцевий пропептид проколагену I типу, нг/мл } & \multicolumn{2}{|c|}{ оксипролін, нг/мЛ } \\
\hline & $\mathrm{M} \pm \mathrm{SE}$ & $\begin{array}{c}\text { частка осіб із низьким } \\
\text { вмістом }(<60 \text { нг/мл) }\end{array}$ & $\mathrm{M} \pm \mathrm{SE}$ & $\begin{array}{l}\text { частка осіб із високим } \\
\text { вмістом }(>16,0 \text { нг/мл) }\end{array}$ \\
\hline \multicolumn{5}{|c|}{ залежно від індексу ушкодження, бали } \\
\hline 1 Індекс ушкодження, $\leq 2$ бали, $n=35$ & $95,4 \pm 6,1$ & $8(22,8 \%)$ & $16,3 \pm 0,64$ & $12(34,2 \%)$ \\
\hline 2 Індекс ушкодження, $\geq 3$ бали, $\mathrm{n}=23$ & $89,3 \pm 8,7$ & $8(34,7 \%)$ & $18,2 \pm 1,03$ & $12(52,2 \%)$ \\
\hline \multicolumn{5}{|c|}{ залежно від активності запального процесу за SLEDAI, бали } \\
\hline 3 SLEDAI, $\leq 18$ балів, $\mathrm{n}=45$ & $97,4 \pm 6,0$ & $11(24,4 \%)$ & $16,6 \pm 0,63$ & $16(35,6 \%)$ \\
\hline 4 SLEDAI, > 18 балів, $\mathrm{n}=13$ & $77,5 \pm 7,0^{*}$ & $5(38,5 \%)$ & $18,7 \pm 1,26$ & $8(61,5 \%)$ \\
\hline
\end{tabular}

Примітка: *-вірогідні відмінності між групами.

Таблиця 5

Зв'язок рівнів С-кінцевого пропептиду проколагену I типу та оксипроліну в сироватці крові з індексом ушкодження та сумарним показником активності запального процесу SLEDAI

\begin{tabular}{|c|c|c|c|c|}
\hline \multirow{3}{*}{ Групи хворих } & \multicolumn{4}{|c|}{ Маркери метаболізму кісткової тканини } \\
\hline & \multicolumn{2}{|c|}{ С-кінцевий пропептид проколагену I типу, нг/мл } & \multicolumn{2}{|c|}{ оксипролін, нг/мЛ } \\
\hline & $\mathrm{M} \pm \mathrm{SE}$ & $\begin{array}{c}\text { частка осіб із низьким } \\
\text { вмістом }(<60 \text { нг/мл) }\end{array}$ & $\mathrm{M} \pm \mathrm{SE}$ & $\begin{array}{l}\text { частка осіб із високим } \\
\text { вмістом }(>16,0 \text { нг/мл) }\end{array}$ \\
\hline \multicolumn{5}{|c|}{ залежно від рівнів ІЛ-6 } \\
\hline 1 Оптимальний (ІЛ-6<12,5 нг/л), $\mathrm{n}=15$ & $106,6 \pm 8,8$ & $1(6,7 \%)$ & $14,6 \pm 0,60$ & $2(13,3 \%)$ \\
\hline 2 Гранично високий (ІЛ-6 12,5-20,0 нг/л), n = 25 & $103,8 \pm 7,7$ & $5(20,0 \%)$ & $16,4 \pm 0,84^{*}$ & $9(36,0 \%)$ \\
\hline 3 Високий (ІЛ-6>20,0 нг/л), $\mathrm{n}=18$ & $64,3 \pm 5,9 *$ & $10(55,6 \%)$ & $20,3 \pm 1,01^{*}$ & $13(72,2 \%)$ \\
\hline 4 Коефіціент кореляції & \multicolumn{2}{|c|}{$-0,24$} & \multicolumn{2}{|c|}{$0,54 *$} \\
\hline \multicolumn{5}{|c|}{ залежно від рівнів СРБ } \\
\hline 5 Оптимальний рівень СРБ $(<7,2$ нг/л), $\mathrm{n}=8$ & $120,9 \pm 6,7$ & $0(0,0 \%)$ & $13,9 \pm 0,55$ & $1(12,5 \%)$ \\
\hline 6 Гранично високий рівень СРБ (7,2-11,8 нг/л), n=25 & $99,1 \pm 8,0^{*}$ & $6(24,0 \%)$ & $16,3 \pm 0,68 *$ & $9(36,0 \%)$ \\
\hline 7 Високий рівень СРБ (>11,8 нг/л), n= 15 & $61,3 \pm 3,8^{*}$ & $10(66,7 \%)$ & $20,7 \pm 1,04^{*}$ & $14(93,3 \%)$ \\
\hline 8 Коефіціент кореляції & \multicolumn{2}{|c|}{$-0,49 *$} & \multicolumn{2}{|r|}{$0,51 *$} \\
\hline
\end{tabular}

Примітка: *-достовірні відмінності між групами.

Таблиця 6

Зв'язок рівнів C-кінцевого пропептиду проколагену I типу та оксипроліну в сироватці крові із сумарною дозою глюкокортикоїдів

\begin{tabular}{|c|c|c|c|c|}
\hline \multirow{3}{*}{ Групи хворих } & \multicolumn{4}{|c|}{ Маркери метаболізму кісткової тканини } \\
\hline & \multicolumn{2}{|c|}{ С-кінцевий пропептид проколагену I типу, нг/мл } & \multicolumn{2}{|c|}{ оксипролін, нг/мЛ } \\
\hline & $\mathrm{M} \pm \mathrm{SE}$ & $\begin{array}{c}\text { частка осіб із низьким } \\
\text { вмістом < } 60 \text { нг/мл) }\end{array}$ & $\mathrm{M} \pm \mathrm{SE}$ & $\begin{array}{l}\text { частка осіб із високим } \\
\text { вмістом }(>16,0 \text { нг/мл) }\end{array}$ \\
\hline 1 Сумарна доза ГК $(<20$ г), $\mathrm{n}=18$ & $93,3 \pm 9,5$ & $4(22,2 \%)$ & $17,0 \pm 1,00$ & $8(44,4 \%)$ \\
\hline 2 Сумарна доза ГК $(20-70$ г), $\mathrm{n}=23$ & $114,4 \pm 7,0$ & $5(21,7 \%)$ & $14,5 \pm 0,54$ & $1(4,3 \%)$ \\
\hline 3 Сумарна доза ГК (>70 г), n=17 & $63,7 \pm 4,5^{*}$ & $7(41,1 \%)$ & $20,5 \pm 0,99^{*}$ & $15(88,2 \%)$ \\
\hline 4 Коефіціент кореляції & \multicolumn{2}{|r|}{$-0,32 *$} & \multicolumn{2}{|r|}{$0,34 *$} \\
\hline
\end{tabular}

Примітка: *-достовірні відмінності між групами.

Оцінювання вмісту маркерів метаболізму кісткової тканини - вмісту С-кінцевого пропептиду проколагену I типу та оксипроліну в сироватці крові хворих на СЧВ показала, що у $39,0 \%$ осіб реєструється іiі пригнічене формування, а у 41,4\% посилена деструкція. У групі контролю частка осіб із низьким вмістом РІСР та високим оксипроліну дорівнювала 6,9\% та 27,5\%, відповідно. Дані літератури також свідчать про подібні зміни метаболічного стану хворих на СЧВ (Teichmann et al., 1999; Guo et al., 2016). Проте існують і такі, які не відмічають відмінностей між метаболічним станом кісткової тканини хворих на СЧВ і практично здорових осіб (Handono et al., 2014).

Посилення деструктивних та зниження біосинтетичних процесів у кістці тісно асоціювалось зі змінами МЩКТ, отриманими методом двоенергетичної рентгенівської абсорбціометрії, а також наявністю переломів. Зокрема, у хворих 3 остеопорозом середній вміст РІСР дорівнював 56,1 $\pm 2,49$ нг/мл, і був на 43,7\% нижчим від такого за нормального стану кістки. Процес рарефікації кістки супроводжувався також вірогідним зростанням концентрації оксипроліну у сироватці крові, рівень якого в осіб з остеопорозом виявився на 28,0\% вищим, ніж в осіб із нормальним станом кістки. Крім того, у хворих із переломами чітко реєструвалося пригнічення біосинтетичних процесів кісткової тканини, на що вказувало вірогідне (на 46,0\%) зниження середніх рівнів РІСР в осіб із переломами порівняно 3 групою без переломів. Літературні дані також чітко вказують на те, що швидкість обміну кісткової тканини достовірно корелює $з$ їі втратою (Stepan, 2000). Незалежно від репродуктивного віку жінки МЩКТ тісно асоціюється з маркерами резорбції кісткової тканини, ніж маркерами біосинтезу (Garnero et al., 1999; Chapurlat et al., 2000; Iki et al., 2006). Водночас, підвищення резорбційної активності прогнозує появу остеопоротичних переломів незалежно від віку, МЩКТ та попередніх 
переломів (Garnero et al., 2000; Ross et al., 2000; Bruyère et al., 2003; Melton et al., 2003).

Збільшення віку хворих на СЧВ також негативно відображається на метаболічному стані кісткової тканини. Зокрема, у хворих старшого віку вміст РІСР був практично на чверть нижчим, ніж у хворих найменшої вікової групи, також пропорційно збільшенню віку вірогідно зростала концентрація оксипроліну у сироватці крові.

Більш чітка тенденція до зростання резорбтивних процесів у кістковій тканині з віком в осіб жіночої статі відмічена і в інших дослідженнях (Bogaczewicz et al., 2015). Водночас, ми не помітили чіткого взаємозв'язку між метаболічними зрушеннями в кістковій тканині 3 тривалістю захворювання, IMT та палінням. Один із несприятливих патогенетичних чинників порушень метаболічного стану кістки - системний запальний процес. Процес старіння кісткової тканини у хворих на СЧВ асоціюються 3 тяжкістю органних уражень і активністю запального процесу. В осіб $з$ високою активністю СЧВ за шкалою SLEDAI (понад 18 балів) рівень С-кінцевого пропептиду проколагену I типу достовірно нижчий, ніж в осіб із відносно низькою активністю СЧВ (SLEDAI $<18$ балів). Основна частка жінок 3 аберантними рівнями С-кінцевого пропептиду проколагену I типу та оксипроліну накопичується саме у групах хворих із високим SLEDAI. Отримані нами дані узгоджуються 3 результатами окремих досліджень, у яких продемонстровано зв'язок між рівнем прозапальних медіаторів і порушеннями метаболічного стану кісткової тканини (Borba et al., 2009; Baker-LePain et al., 2011). Водночас Hansen et al. (1998) не виявили взаємозв'язків між маркерами обміну кісткової тканини та тяжкістю перебігу СЧВ.

Хоча патогенетичні механізми взаємодії імунної та кісткової систем організму людини досі залишаються недостатньо вивченими, вважається, що деструкція кісткової тканини у хворих на системний червоний вовчак - результат прискореного остеокластогенезу, активованого прозапальними цитокінами (Amarasekara et al., 2015). Підвищений вміст ФНП-альфа, ІЛ-1, -6 та ІЛ-17 у хворих на СЧВ спричинюе порушення співвідношення RANKL/OPG у бік збільшення синтезу першого, що лежить в основі інтенсивного дозрівання остеокластів (Amarasekara et al., 2015).

Наведені нами дані демонструють, що вміст СРБ та ІЛ-6 у сироватці крові виявляє сильний прямий кореляційний зв'язок iз рівнем оксипроліну та обернений зв'язок із рівнем С-кінцевого пропептиду проколагену I типу. Наші дані узгоджуються 3 результатам досліджень Korczowska et al. (2003) та Borba et al. (2009), в яких продемонстровано зв'язок між рівнем прозапальних медіаторів і посиленням ознак кісткової деструкції у хворих на СЧВ. Цікавим виявилось повідомлення BakerLePain et al. (2011), в якому вказується, що висока активність захворювання інтенсивніше стимулює процеси резорбції кісткової тканини, ніж кістковоутворення.

Ще один із несприятливих чинників для стану кісткової тканини у хворих на СЧВ - глюкокортикоїдна терапія. ГК порушують дозрівання та активність остеобластів, скорочують тривалість життя кісткових клітин, пригнічують дію місцевих факторів росту (Canalis et al., 2007). Одразу після початку лікування ГК відмічається персистуюче пригнічення процесів формування кісткової тканини та швидке, проте транзиторне посилення резорбтивних процесів (Dovio et al., 2004). Ми показали, що зростання сумарної дози ГК у жінок із СЧВ супроводжувалось достовірним збільшенням концентрації оксипроліну та зниженням РІСР у сироватці крові. Додаткові докази патогенетичного зв'язку між використанням ГК і патологічним ремоделюванням кісткової тканини були отримані завдяки кореляційному аналізу. 3'ясувалось, що між сумарною дозою ГК та рівнем РІСР у сироватці крові встановлюються обернені кореляційні зв'язки, а між дозою ГК і оксипроліном - прямі вірогідні $(\mathrm{r}=-0,32, \mathrm{r}=0,34$, відповідно).

Отримані нами дані свідчать, що у жінок із СЧВ відбу- вається формування несприятливого метаболічного патерну: зростання рівнів оксипроліну та зниження рівнів РІСР у сироватці крові. Висока активність запального процесу та тривале використання ГК, як і збільшення віку, - фактори формування порушень метаболічного стану кісткової тканини у пацієнток із СЧВ. Цілком імовірно, що корекція активності захворювання та асоційованих із ним метаболічних порушень дозволить уповільнити прогресування несприятливих структурно-функціональних змін кісткової тканини у жінок із СЧВ.

\section{Висновки}

У $39,0 \%$ жінок із СЧВ має місце зниження рівня маркера біосинтезу кісткової тканини - С-кінцевого пропептиду проколагену I типу та у 41,4\% підвищення маркера кісткової резорбції- оксипроліну.

Метаболічний дисбаланс кісткової тканини доволі тісно асоціюється $з$ тяжкістю перебігу захворювання, активністю запального процесу, особливо високими рівнями СРБ та ІЛ-6, віком хворих та високою сумарною дозою глюкокортикоїдів і суттєво не залежить від тривалості захворювання, IMT та паління.

У групі хворих $з$ ознаками пригнічення біосинтетичних $\mathrm{i}$ посиленням деструктивних процесів у кістковій тканині достовірно частіше зустрічаються особи з остеопенічним синдромом і остеопорозом, а також із переломами.

\section{References}

Ajeganova, S., Gustafsson, T., Jogestrand, T., Frostegard, J., \& Hafström, I (2015). Bone mineral density and carotid atherosclerosis in systemic lupus erythematosus: A controlled cross-sectional study. Arthritis Research and Therapy, 17, 84.

Amarasekara, D. S., Yu, J., \& Rho, J. (2015). Bone loss triggered by the cytokine network in inflammatory autoimmune diseases. Journal of Immunology Research, 2015, 832127.

Baker-LePain, J. C., Nakamura, M. C., Shepherd, J., \& von Scheven, E. (2011). Assessment of bone remodelling in childhood-onset systemic lupus erythematosus. Rheumatology (Oxford), 50(3), 611-619.

Becker, A., Fischer, R., Scherbaum, W. A., \& Schneider, M. (2001). Osteoporosis screening in systemic lupus erythematosus: Impact of disease duration and organ damage. Lupus, 10(11), 809-814.

Bogaczewicz, J., Karczmarewicz, E., Pludowski, P., Zabek, J., Kowalski, J., Lukaszkiewicz, J., \& Wozniacka, A. (2015). Feasibility of measurement of bone turnover markers in female patients with systemic lupus erythematosus. Revista Brasiliera de Reumatologia, 55(2), 133-139.

Bombardier, C., Gladman, D. D., Urowitz, M. B., Caron, D., \& Chang, C. H. (1992). Derivation of the SLEDAI. A disease activity index for lupus patients. The Committee on Prognosis Studies in SLE. Arthritis and Rheumatology, 35(6), 630-640.

Borba, V. Z., Vieira, J. G., Kasamatsu, T., Radominski, S. C., Sato, E. I., \& Lazaretti-Castro, M. (2009). Vitamin D deficiency in patients with active systemic lupus erythematosus. Osteoporosis International, 20(3), 427-433.

Bruyere, O., Collette, J., Delmas, P., Rouillon, A., Roux, C., Seidel, L., Richy, F., \& Reginster, J. Y. (2003). Interest of biochemical markers of bone turnover for long-term prediction of new vertebral fracture in postmenopausal women. Maturitas, 44(4), 259-265.

Bultink, I. E. (2012). Osteoporosis and fractures in systemic lupus erythematosus. Arthritis Care and Research (Hoboken), 64(1), 2-8.

Bultink, I. E., \& Lems, W. F. (2016). Lupus and fractures. Current Opinion in Rheumatology, 28(4), 426-432.

Canalis, E., Mazziotti, G., Giustina, A., \& Bilezikian, J. P. (2007). Glucocorticoidinduced osteoporosis: Pathophysiology and therapy. Osteoporosis International, 18(10), 1319-1328.

Carli, L., Tani, C., Spera, V., Vagelli, R., Vagnani, S., Mazzantini, M., Di Munno, O., \& Mosca, M. (2016). Risk factors for osteoporosis and fragility fractures in patients with systemic lupus erythematosus. Lupus Science and Medicine, 3(1), e000098

Chapurlat, R. D., Garnero, P., Sornay-Rendu, E., Arlot, M. E., Claustrat, B., \& Delmas, P. D. (2000). Longitudinal study of bone loss in pre- and perimenopausal women: Evidence for bone loss in perimenopausal women. Osteoporosis International, 11(6), 493-498.

Cramarossa, G., Urowitz, M. B., Su, J., Gladman, D., \& Touma, Z. (2016). Prevalence and associated factors of low bone mass in adults with systemic lupus erythematosus. Lupus, 2016. 
Dovio, A., Perazzolo, L., Osella, G., Ventura, M., Termine, A., Milano, E., Bertolotto, A., \& Angeli, A. (2004). Immediate fall of bone formation and transient increase of bone resorption in the course of high-dose, short-term glucocorticoid therapy in young patients with multiple sclerosis. Journal of Clinical Endocrinology and Metabolism, 89(10), 4923-4938.

Garnero, P., Sornay-Rendu, E., Claustrat, B., \& Delmas, P. D. (2000). Biochemical markers of bone turnover, endogenous hormones and the risk of fractures in postmenopausal women: The OFELY study. Journal of Bone and Mineral Research, 15(8), 1526-1536.

Garnero, P., Sornay-Rendu, E., Duboeuf, F., \& Delmas, P. D. (1999). Markers of bone turnover predict postmenopausal forearm bone loss over 4 years: The OFELY study. Journal of Bone and Mineral Research, 14(9), 1614-1621.

Gladman, D., Ginzler, E. Goldsmith, C., Fortin, P., Liang, M., Urowitz, M., Bacon, P., Bombardieri, S., Hanly, J., Hay, E., Isenberg, D., Jones, J., Kalunian, K., Maddison, P., Nived, O., Petri, M., Richter, M., SanchezGuerrero, J., Snaith, M., Sturfelt, G., Symmons, D., \& Zoma, A. (1996). The development and initial validation of the Systemic Lupus International Collaborating Clinics/American College of Rheumatology damage index for systemic lupus erythematosus. Arthritis and Rheumatology, 39(3), 363-369.

Guo, Q., Fan, P., Luo, J., Wu, S., Sun, H., He, L., \& Zhou, B. (2016). Assessment of bone mineral density and bone metabolism in young male adults recently diagnosed with systemic lupus erythematosus in China. Lupus, 26(3).

Handono, K., Sari, T. L., \& Adam, A. A. (2014). Homocysteine, folic acid, vitamin B6, vitamin B12, and biochemical parameters of bone metabolism in female patients with systemic lupus erythematosus. Journal of Clinical and Cellular Immunology, 5(3), 217.

Hansen, M., Halberg, P., Kollerup, G., Pedersen-Zbinden, B., Hørslev-Petersen, K., Hyldstrup, L., \& Lorenzen, I. (1998). Bone metabolism in patients with systemic lupus erythematosus. Effect of disease activity and glucocorticoid treatment. Scandinavian Journal of Rheumatology, 27(3), 197-206.

Hochberg, M. C. (1997). Updating the american college of rheumatology revised criteria for the classification of systemic lupus erythematosus. Arthritis and Rheumatology, 40(9), 1725-1734.

Iki, M., Morita, A., Ikeda, Y., Sato, Y., Akiba, T., Matsumoto, T., Nishino, H., Kagamimori, S., Kagawa, Y., Yoneshima, H., \& JPOS Study Group (2006). Biochemical markers of bone turnover predict bone loss in perimenopausal women but not in postmenopausal women - the Japanese Population - based Osteoporosis (JPOS) Cohort Study. Osteoporosis International, 17(7), 1086-1095.

Korczowska, I., Olewicz-Gawlik, A., Hrycaj, P., \& Lacki, J. (2003). The effect of long-term glucocorticoids on bone metabolism in systemic lupus erythematosus patients: The prevalence of its anti-inflammatory action upon bone resorption. Yale Journal of Biology and Medicine, 76(2), 45-54.
Li, E. K., Tam, L. S., Griffith, J. F., Zhu, T. Y., Li, T. K., Li, M., Wong, K. C., Chan, M., Lam, C. W., Chu, F. S., Wong, K. K., Leung, P. C., \& Kwok, A. (2009). High prevalence of asymptomatic vertebral fractures in Chinese women with systemic lupus erythematosus. Journal of Rheumatology, 36(8), 1646-1652.

Melton, L. J. 3rd., Crowson, C. S., O'Fallon, W. M., Wahner, H. W., \& Riggs, B. L. (2003). Relative contribution of bone density, bone turnover, and clinical risk factors to long-term fracture prediction. Journal of Bone and Mineral Research, 18(2), 312-318.

Mendoza-Pinto, C., García-Carrasco, M., Sandoval-Cruz, H., Muñoz-Guarneros, M., Escárcega, R. O., Jiménez-Hernández, M., Munguía-Realpozo, P., Sandoval-Cruz, M., Delezé-Hinojosa, M., López-Colombo, A., \& Cervera, R. (2009). Risk factors of vertebral fractures in women with systemic lupus erythematosus. Clinical Rheumatology, 28(5), 579-585.

Redlich, K., Ziegler, S., Kiener, H. P., Spitzauer, S., Stohlawetz, P., Bernecker, P., Kainberger, F., Grampp, S., Kudlacek, S., Woloszczuk, W., Smolen, J. S., \& Pietschmann, P. (2000). Bone mineral density and biochemical parameters of bone metabolism in female patients with systemic lupus erythematosus. Annals of the Rheumatic Diseases, 59(4), 308-310.

Rees, F., Doherty, M., Grainge, M., Lanyon, P., Davenport, G., \& Zhang, W. (2016). Burden of comorbidity in systemic lupus erythematosus in the UK. Arthritis Care and Research (Hoboken), 68(6), 819-827.

Ross, P. D., Kress, B. C., Parson, R. E., Wasnich, R. D., Armour, K. A., \& Mizrahi, I. A. (2000). Serum bone alkaline phosphatase and calcaneus bone density predict fractures: A prospective study. Osteoporosis Interbational, 11(1), 76-82.

Stepan, J. J. (2000). Prediction of bone loss in premenopausal women. Osteoporosis International, 11(3), 545-554.

Sun, Y. N., Feng, X. Y., He, L., Zeng, L. X., Hao, Z. M., Lv, X. H., \& Pu, D. (2015). Prevalence and possible risk factors of low bone mineral density in untreated female patients with systemic lupus erythematosus. Biomed Research International, 2015, 510-514.

Tang, Y., Xie, H., Chen, J., Geng, L., Chen, H., Li, X., Hou, Y., Lu, L., Shi, S., Zeng, X., \& Sun, L. (2013). Activated NF- $\kappa B$ in bone marrow mesenchymal stem cells from systemic lupus erythematosus patients inhibits osteogenic differentiation through downregulating Smad signaling. Stem Cells and Development, 22(4), 668-678.

Teichmann, J., Lange, U, Stracke, H., Federlin, K., \& Bretzel, R. G. (1999). Bone metabolism and bone mineral density of systemic lupus erythematosus at the time of diagnosis. Rheumatology International, 18(4), 137-140.

Wang, X., Yan, S., Liu, C., Xu, Y., Wan, L., Wang, Y., Gao, W., Meng, S., Liu, Y., Liu, R., \& Xu, D. (2016). Fracture risk and bone mineral density levels in patients with systemic lupus erythematosus: A systematic review and metaanalysis. Osteoporosis International, 27(4), 1413-1423. 